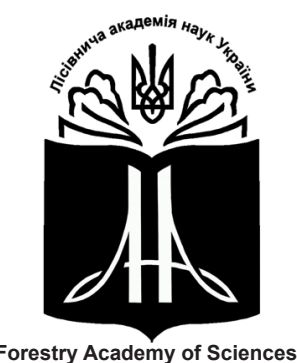

of Ukraine

Наукові праці Лісівничої академії наук України

Proceedings of the Forestry Academy of Sciences of Ukraine

http://fasu.nltu.edu.ua

https://doi.org/ 411709

Article received 2017.09.04

Article accepted 2017.11.15
ISSN 1991-606X print

ISSN 2616-5015 online

(a) $\triangle$ Correspondence author

N. Gatalska

gatalska@ukr.net

УДК $630 * 27$

\title{
Теоретичні аспекти функціонального призначення парків як основа для формування підходів до оцінювання естетичних якостей паркового середовища
}

\author{
Н.О. Олексійченко ${ }^{1}$, Н. В. Гатальська²
}

Виявлено принципову різницю у підходах, наукових стратегіях і методах, які застосовують у дослідженнях естетики природних та штучно створених ландшафтів.

Оиінювання естетичної привабливості природних ландшафтів грунтується на визначенні потенційних функцій середовища, а саме спрямовано на виявлення найцінніших ландшафтних угруповань для їх збереження та використання результатів такого оцінювання у формуванні перспективних напрямів розвитку регіону, адаптації окремих територій до потреб населення. Дослідження естетичних якостей ландшафту штучно створених парків різного функиіонального призначення здійснюють для визначення рівня їх відповідності сучасним потребам людини та функціям, щзо на них покладені.

Виявлено, щзо ключовим питанням у формуванні підходів та визначенні методів дослідження паркового середовища є його функиіональне призначення, щуо нерозривно пов'язано з композиційною структурою міста, а їх невідповідність призводить до погіршення стану паркового середовища, шьо негативно впливає як на екологію, так і естетику урбосередовища загалом.

Запропоновано концептуальну схему формування програми дослідження естетичних якостей паркового ландшафту, яка базується на функиіональному призначенні (сучасному або потениійному) дослідного об 'єкту та передбачає п'ять взаємопов'язаних етапів.

Ключові слова: функиії парку, пейзажно-композиційний підхід, естетика ландшафту, методологія естетики

Вступ. Дослідження естетичних якостей ландшафту беруть свій початок у $20-x$ роках XX ст., коли Alfred Hettner (1927) запропонував виділити науковий напрям - естетичну географію, заклавши методологічні основи напряму та сприявши розвитку покомпонентного оцінювання естетичної цінності території. Важливим в обгрунтуванні його теорії було зосередження уваги на питанні об'єктивності оцінювання естетичної привабливості ландшафту.

Упродовж XX ст. у межах поведінкової географії, як результат взаємодії естетики і ландшафтознав- ства, розвинувся новий науковий напрям - естетика ландшафту, в межах якого досліджують зовнішній вигляд ландшафту (пейзаж) як особливий вид відновлюваного ресурсу, а також ландшафт як об'єкт різних форм естетичного сприйняття людиною, що впливає на іï психологічний комфорт (Nikolaev, 2005, Hrozdynskyi \& Savytska 2005).

Розвитком естетики ландшафту як наукового напряму зумовлено фокусування уваги вчених на двох аспектах - виявленні найпривабливіших для людського сприйняття ландшафтів та дослідженні

\footnotetext{
Олексійченко Надія Олександрівна - дійсний член Лісівничої академії наук України, доктор сільськогосподарських наук, професор кафедри ландшафтної архітектури та садово-паркового будівництва. Національний університет біоресурсів і природокористування України, вул. генерала Родімцева, 19, м. Київ, 03041, Україна. Тел.: 044-227-82-96, +38-098-330-22-78. E-mail: nadiaolex@ukr.net

2 Гатальська Надія Вікторівна - кандидат сільськогосподарських наук, доцент кафедри ландшафтної архітектури та садово-паркового будівництва. Національний університет біоресурсів і природокористування України, вул. генерала Родімцева, 19, м. Київ, 03041, Україна. Тел.: 044-227-82-96, +38-067-728-69-20. E-mail: gatalska@ukr.net
} 
об'єктивних причин різниці такого сприйняття. Зосередження уваги вчених на об'єктивних факторах, що впливають на естетичну привабливість ландшафтів, сприяло розвитку підходів та методів дослідження матеріальних форм ландшафту. Водночас центральне місце в дослідженнях інших вчених займала людина, як суб'єкт сприйняття та оцінювання естетики ландшафту (Kaymaz, 2012).

Важливим аспектом розвитку досліджень естетики ландшафту $є$ зосередження наукових знань довкола:

- естетики природних ландшафтів, які займають значні простори, формуються без участі людини та упродовж тривалого періоду часу;

- естетики міського середовища, як автономної структури, що формується людиною відповідно до іiі потреб, технічних можливостей, естетичних поглядів тощо.

У цьому контексті варто зауважити, що паркові ландшафти залежно від їх особливостей можна розглядати як частину природного ландшафту (природні ландшафтні парки, біосферні заповідники) або ж компоненти міського середовища (міські парки різного функціонального призначення, що розташовані в межах населених пунктів 3 наявністю значної частки штучно створених компонентів). Важливо, що естетичним об'єктом природних ландшафтів є саме природна форма, тоді як в об'єкті містобудування природна форма краси заміщується штучною. Своєю чергою естетичний об'єкт паркових ландшафтів є природною фрмою, яка зазнала перетворень та $є$ втіленням естетичних поглядів певного соціуму, групи людей або індивіда, що виступив у ролі проектанта, проте уособлює певні ідеологічні та естетичні концепції.

3 огляду на це, варто зауважити на принциповій різниці підходів до вивчення естетики природних та штучно створених ландшафтів, зумовлених метою проведення зазначених досліджень. Відтак аналіз естетичної привабливості природних ландшафтів проводять для визначення найцінніших ландшафтних угруповань для їх збереження та використання результатів такого оцінювання під час формування перспективних напрямів розвитку регіону, адаптації окремих територій до потреб населення тощо. Отже, досліджують потенційні функції, які може виконувати ландшафт як природо-охоронний або рекреаційний об'єкт. Поряд із тим, дослідження естетичних якостей ландшафту штучно створених парків різного функціонального призначення здійснюють для визначення рівня їх відповідності сучасним потребам та функціям, що на них покладені.

Важливим загальним аспектом дослідження природного, міського та паркового ландшафту як естетичного об'єкта є мультисенсорність сприйняття його середовища (відбувається завдяки всім органам чуття), що принципово відрізняється від творів мистецтва, які розраховані на візуальну сферу сприйняття (твори образотворчого мистецтва) або слух (музика). Поряд із мільтисенсорістю сприйняття парковий пейзаж, зазвичай, неможливо охопити одразу, сприйнят- тя відбувається як серія пейзажів (Ungar, 1999, Foster, 2010, van Etteger, Thompson \& Vera Vicenzotti, 2016).

3 огляду на наведене вище $\epsilon$ підстави говорити про функцію (наявну та (або) потенційну) як основу, що визначає підходи та методи дослідження естетики паркового ландшафту.

Об'єкти та методика досліджень. Об'єкт дослідження - функції ландшафту як визначальний фактор формування підходів та методів аналізу його естетичних якостей.

Предмет дослідження - взаємозалежність підходів та методів дослідження естетики ландшафту та його функціонального призначення.

Мета досліджень - визначити роль функції ландшафту як визначального фактора у формуванні підходів та методів аналізу його естетичних якостей.

Матеріалами для досліджень слугували результати аналізу наукових джерел літератури, які стосуються теоретико-методологічних аспектів дослідження естетики ландшафту. В основу досліджень покладено загальнонаукові методи пізнання (аналіз, системний підхід, синтез). Дослідження базується на поняттях і принципах середовищного підходу оцінювання ландшафту, а також на порівняльному аналізі суб'єктно-об'єктно-орієнтованих підходів і методів дослідження, що відповідає положенням системного підходу та збігається із загальними тенденціями у сучасних наукових дослідженнях.

Результати досліджень. Упродовж останніх десятиліть дедалі актуальнішим стає питання оцінювання естетичних якостей природних та антропогенних ландшафтів за допомогою як загальноприйнятих, так і спеціальних методів дослідження. Зокрема, взаємозв'язки між преференціями пейзажів та їх картографічними показниками ландшафтної структури вивчали Dramstad et al. (2006) та виявили суттєві позитивні кореляції між перевагами та просторовими показниками, враховуючи кількість типів земель та різноманітність земельних ділянок. Filova, Vojar, Svobodova \& Sklenicka (2015) досліджували візуальні якості ландшафтів, а саме сприйняття обраних елементів у ландшафті.

На важливості аналізу зв'язків між візуальною якістю та структурними особливостями ландшафту, як ефективного способу проведення когнітивних досліджень, наголошують Darabi, Razavi \& Vaeziheir (2017), які на основі результатів оцінювання естетичних якостей ландшафтів автостради Тегеран Кум поблизу північно-східної сторони Міжнародного аеропорту імама Хомейні (Іран) та сприйняття їх людиною, розробили стратегічний план збереження та відновлення екологічного ландшафту.

Наведені дослідження зосереджені на оцінюванні естетичних якостей природних ландшафтних угруповань, сільськогосподарських угідь, а також територій, трансформованих унаслідок розвитку інфраструктури регіону, а не потребою створення рекреаційного об'єкта. Теоретичною основою для таких досліджень $є$ пейзажні підходи до вивчення естетики ландшафту, методологічною - парадигма естетичних вподобань (за Osychenko (2015) або психофізична парадигма (за Zube, Sell \& Taylor 
(1982), в основу яких покладено аналіз естетичних якостей ландшафту окремого спостерігача, шляхом тестування громадськості. Варто зазначити, що пейзажний підхід у дослідженнях естетичних якостей об'єктів вперше виокремила G. Osychenko, (2012), яка відносить сюди дослідження, що вирізняються візуальною спрямованістю та зосереджують увагу на вивченні якостей зорового кадру.

Водночас дослідження штучно створених парків різного функціонального призначення, розміщених як на території міст, так і за їх межами базуються, головним чином, на покомпонентному оцінюванні ландшафту та здійснюються експертами з використанням описових, кількісних i якісних методів, які спираються на знання і професійні норми дослідника (експертна парадигма за Zube, Sell \& Taylor (1984) та Osychenko, (2015). Залучення громадськості за таких умов не передбачено. Результати досліджень парків різного функціонального призначення, теоретичною основою якого є покомпонентний підхід, наведено у наукових працях Dudyn (2009), Klymenko (2010, 2011), Oleksiichenko \& Gatalska (2012), Gatalska \& Lazarenko (2012) та ін.

До теоретичних робіт, в яких досліджено методи та формування методик покомпонентного вивчення паркових територій різного функціонального призначення, можна віднести роботи таких вчених, як Galushko (1999), Khoroshikh \& Khoroshikh (1999), Hrynasiuk (2014) та ін. Деякі методики (Margailik \& Kirilchik (1979), Kurdiuk (1982), Kucheriavyi (1991) передбачають аналіз пейзажних картин, що є характерним для пейзажного підходу, однак більшість їх критеріїв сфокусована на параметризації компонентів паркового середовища, а також визначенні їх якісних та кількісних характеристик.

3 огляду на проведений аналіз наукових досліджень, що охоплюють питання вивчення естетики паркових ландшафтів, виявлено необхідність уточнення пейзажного підходу, виділеного Osychenko (2012), яка зумовлена наявністю значної кількості теоретичних та прикладних робіт (Eringis \& Budryunas (1975), Kurbatov (1988), Motoshyna\& Vdoviuk (2012), Oleksiichenko \& Gatalska (2012) та ін.), які включають не лише оцінювання якостей зорового кадру, але й враховують значення композиційної структури ландшафтного об'єкта або окремих ㄲi компонентів. Предметом пейзажнокомпозиційного підходу є композиційна узгодженість компонентів ландшафту загалом та деяких пейзажів зокрема. До методів, які застосовують у межах пейзажно-композиційного підходу, належать графоаналітичний та композиційний аналіз, фотофіксація, описи, експертна оцінка. Ступінь естетичної привабливості можна визначити як на основі сумарної кількості балів, означених критеріями, так і відповідно до характеристик, наданих експертами в описовій формі.

Отже, пейзажно-композиційний підхід оцінювання естетичних якостей ландшафтів об'єднує дослідження композиційної структури (або окремих ii складових) об’єкта в поєднанні 3 аналізом певних пейзажів - пейзажних картин та панорам (рис. 1). У межах пейзажно-композиційного підходу дослідження естетики ландшафту можуть передбачати як проведення експертної оцінки, так і аналіз естетичних вподобань респондентів шляхом їх опитування.

Одним із методів естетичних вподобань (дослідження суб' єктивного сприйняття ландшафту) є метод, який розробив Kane (1981), що спрямований на оцінювання респондентами певних структур ландшафту та фіксацію їх емоційної або асоціативної реакції на загальний вигляд пейзажу. Метод передбачає анкетування респондентів за шістьма категоріями - форми рельєфу, вода, рослинний покрив, діяльність людини, композиційні чинники (наприклад, кольорова різноманітність, видимість, хмарність тощо). Головним елементом ландшафтної структури $є$ рельєф, як основний чинник формування привабливого пейзажу. У процесі оцінювання рельєфу враховують його форму, глибину, розчленування, перепад висоти, стрімкість схилів, розчленованість, а також наявність морфоскульптурних форм.

Суть методу, який розробив Каne (1981), полягає в оцінці пейзажу за набором якісних показників та ступенем їх прояву за 7-бальною шкалою. Анкетна форма, яку пропонують респондентам, містить 21 пару прикметників, якими можна охарактеризувати емоційну реакцію на пейзаж.

Загалом, психофізичні методи оцінювання естетичності ландшафту об'єктивніші, ніж методи бального оцінювання, що зумовлює їх пріоритетність у сучасних дослідженнях 3 естетики ландшафту (Hrozdynskyi \& Savytska, 2005), однак їх здебільшого використовують для дослідження природних ландшафтних угруповань та їх потенційних функцій (Dramstad et al. (2006), Filova, Vojar, Svobodova \& Sklenicka (2015), Darabi, Razavi \& Vaeziheir (2017) та ін.).

Експертне оцінювання пейзажів передбачає аналіз об'ємно-просторової композиції ландшафтного об'єкта, як формальної композиції, так і як системи пейзажних картин, які сприймаються під час поступального руху або панорамного огляду (див. рис. 1). Своєю чергою, пейзажна картина, як фрагмент паркового середовища, визначається властивостями взаємопов'язаних структур - об 'ємно-просторової, графічної, колірної, текстурної та фактурної (Kurbatov, 1988).

До пейзажно-копозиційних підходів дослідження естетики ландшафту із залученням експертів відносять методику, наведену у Методичних рекомендаціях проведення естетичної оцінки території з метою заповідання для працівників мережі установ Міністерства екоресурсів України, науковців, природоохоронців (2003). Важливість цього методичного підходу полягає в орієнтуванні методики на рекреаційні потреби людей, що є одним 3 фундаментальних аспектів для оцінювання ландшафту, до потенційних функцій якого належить забезпечення рекреації.

Досить різноплановим $є$ підхід до оцінювання естетичних якостей ландшафтів для їх рекреаційного використання, запропонований Motoshyna \& 
Vdoviuk (2012), що включає низку критеріїв та шкали балів для них. Таким чином, отримують окремі оцінки (для кожного критерію). Сумарна оцінка ландшафту загалом виводиться через сукупність окремих показників (табл.). Автори прийняли, що найціннішими ландшафтами $є$ такі, що отримали в сумі 15-20 балів, високоцінними - 10-14, середньої цінності - 5-9, малоцінні - 1-4 бали.

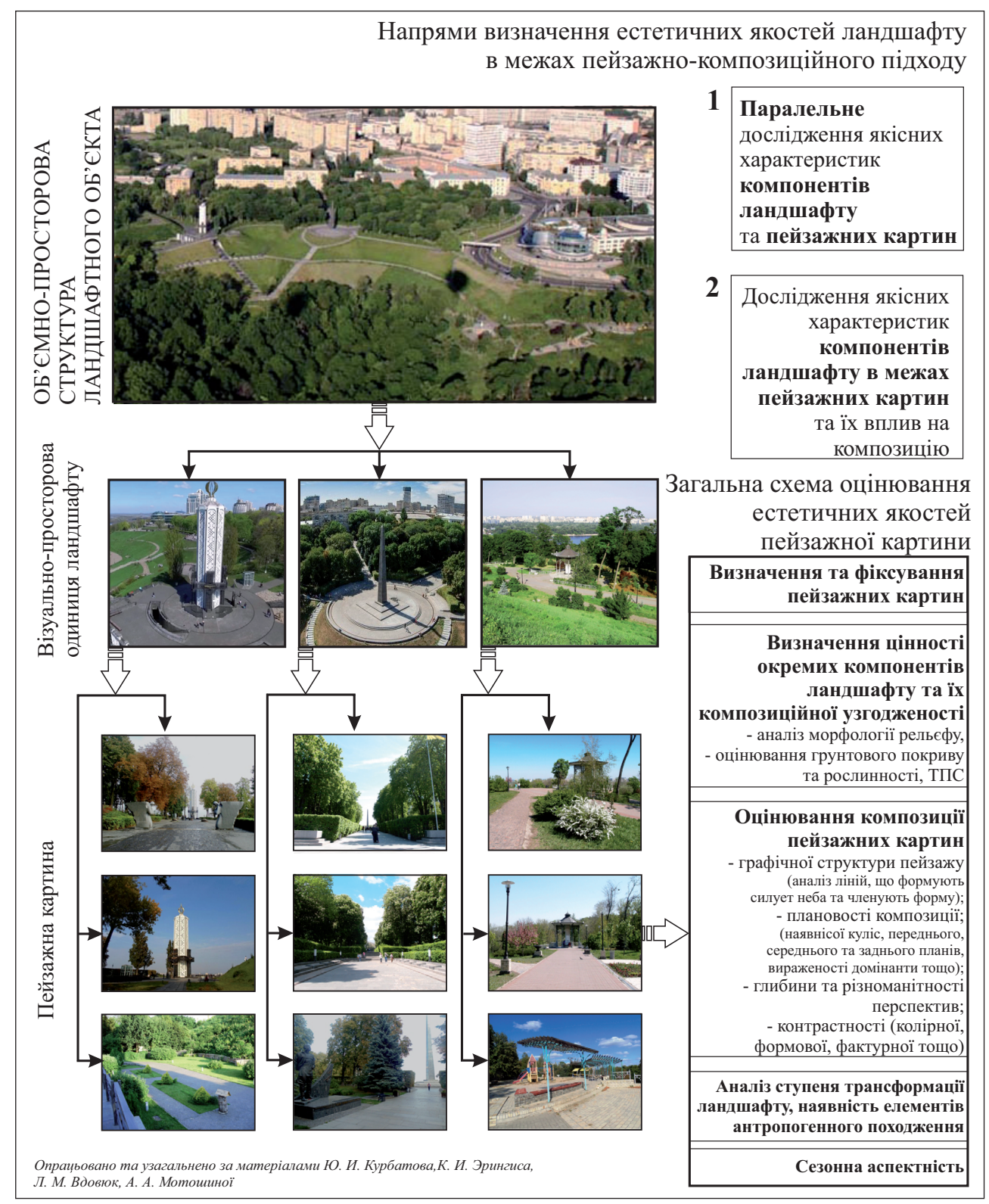

Рис. 1. Концептуальна схема пейзажно-композмційного підходу дослідження естетичних якостей ландшафту

Відповідно до результатів оцінювання пропонують ранжування пейзажів відповідно до їх естетичної цінності. Дискусійним питанням у наведеному методі $є$ винесення в критерії оцінювання символічних об'єктів, що є суб'єктивним фактором, тоді як усі інші критерії є об'єктивними та не передбачають залучення респондентів.

Значний внесок у розвиток теорії естетики ландшафту 3 погляду аналізу його пейзажів зробили Eringis \& Budryunas (1975), під керівництвом яких литовські науковці розробили методику, що передбачає аналіз естетичних якостей пейзажів на основі детального вивчення компонентів ландшафту та їх композиційної узгодженості за низкою критеріїв. Виділені критерії поділено на три групи, які відображають спе- цифічні особливості. До першої групи віднесено природні об'єкти (озера, масиви дерев тощо), які можуть бути арифметично розраховані. Друга група характеризує загальні ознаки пейзажу - глибина та розмаїття перспектив, багатоплановість, сезонність та ін. До третьої групи автори віднесли об'єкти, які можуть як покращувати естетичні якості пейзажів, як і погіршувати їх - це об'єкти людської життєдіяльності.

Загальна оцінка за всіма критеріями і надає уявлення щодо естетичних якостей ландшафту (Eringis \& Budryunas, 1975). Важливим аспектом запропонованого методу є врахування сезонних змін, які відбуваються у природі та впливають на естетику ландшафту. В цьому контексті доцільно звернути увагу на працю «Landscape Planning», в якій автор 
визначає пейзаж як «...складне явище, яке постійно розвивається у просторі та часі.....», також роблячи наголос на його мінливості (Kaymaz, 2012, p. 251).

Пейзажні, пейзажно-композиційні та покомпонентні підходи, стратегії та методи дослідження естетичних якостей ландшафту покладено в основу комплексного оцінювання територій парків різного функціонального призначення в контексті перспективи їх використання або виконання ними низки функцій. Естетична привабливість у цьому разі нерозривно пов'язана з функціональним призначенням паркового об'єкта.

Серед підходів дослідження штучно створених парків, які передбачають визначення відповідності характеристик паркового ландшафту його функціональному призначенню, на увагу заслуговують науково-методичні підходи до оцінювання культурно-історичної цінності парків, а також методика визначення дендрологічної цінності парків, які розробили Oleksiichenko \& Gatalska (2012). Предметом дослідження є особливості формування та розвитку паркового ландшафту, а естетичну цін- ність розглядають через призму значення парку як об'єкта культурно-історичної та наукової спадщини. Поряд 3 оцінюванням компонентів паркового ландшафту та композиційної структури - іï цілісності та рівня збереженності (характерно для покомпонентних і формально-композиційних теорій відповідно) наведені методики передбачають проведення комплексних передпроектних досліджень, предметом яких є визначення історичних аспектів формування території.

Функція парку лежить в основі методу оцінювання культурно-історичної цінності та засобів вираження ідейного навантаження меморіальних парків (Oleksiichenko et al., 2017). Цікавим у межах наведеного методу є аналіз вираження ідейного навантаження парку через прямі та опосередковані засоби, тобто інформаційні структури, які можуть бути сприйняті через когнітивну сферу сприйняття людини. Наведені функціональні підходи мають прикладний характер та передбачають проведення оцінювання експертом, тобто базуються на експертній парадигмі.

Таблиця

Шкала оцінки пейзажно-естетичної цінності ландшафтів (Motoshyna \& Vdoviuk (2012)

\begin{tabular}{|c|c|c|c|}
\hline $\begin{array}{l}\text { № } \\
3 \backslash \text { П }\end{array}$ & \multicolumn{2}{|c|}{ Оцінковий показник естетичної привабливості ландшафтів } & Бал \\
\hline \multirow{4}{*}{1} & \multirow{4}{*}{$\begin{array}{l}\text { Контрастність ландшафтів - різноманітність } \\
\text { структурно різнорідних комплексів (СРК) }\end{array}$} & Весь пейзажний вид складається з 1-2 СРК & 1 \\
\hline & & У пейзажі наявні від 2 до 4 СРК з переважанням 1-2 & 2 \\
\hline & & Пейзаж має більше 4 СРК з переважанням 3-4 & 3 \\
\hline & & Однакова питома вага площ більше СРК & 2 \\
\hline \multirow{4}{*}{2} & \multirow{4}{*}{ Кольорова гама пейзажу } & Чорний, темно-сірий & 0 \\
\hline & & Світло-сірий, коричневий & 1 \\
\hline & & Блакитний, зелений & 2 \\
\hline & & $\begin{array}{c}\text { Блакитний, зелений з контрастними кольорами - } \\
\text { жовтим, білим, червоним тощо }\end{array}$ & 3 \\
\hline \multirow{3}{*}{3} & \multirow{3}{*}{ Глибина перспективи } & Фронтальна & 1 \\
\hline & & Об’ємна & 2 \\
\hline & & Глибинно-просторова & 3 \\
\hline \multirow{3}{*}{4} & \multirow{3}{*}{$\begin{array}{l}\text { Наявність водних об’єктів у ландшафтній } \\
\text { структурі, їх якість і кількість }\end{array}$} & Відсутні & 0 \\
\hline & & Озера (чисті\забруднені) & $1 \backslash-1$ \\
\hline & & Річки (чисті\забруднені) & $1 \backslash-1$ \\
\hline \multirow{6}{*}{5} & \multirow{6}{*}{ Лісистість, \% } & 0 & 0 \\
\hline & & $1-15$ & 1 \\
\hline & & $16-30$ & 2 \\
\hline & & $30-60$ & 3 \\
\hline & & $61-85$ & 2 \\
\hline & & Більше 85 & 1 \\
\hline \multirow{4}{*}{6} & \multirow{4}{*}{$\begin{array}{l}\text { Ступінь антропогенної трансформації ланд- } \\
\text { шафтів }\end{array}$} & Умовно незмінний ландшафт & 3 \\
\hline & & Істинно культурний ландшафт & 2 \\
\hline & & Мало змінений ландшафт & 1 \\
\hline & & Порушений ландшафт & -3 \\
\hline \multirow{2}{*}{7} & Наявність у ландшафтах символічних & Відсутні & 0 \\
\hline & об’єктів & Присутні & 1 \\
\hline
\end{tabular}

Функціональним спрямуванням характеризується методика оцінювання ландшафтів за їх сприятливістю до рекреаційної діяльності, розроблена
Tsaryk \& Cherniuk (2001), що передбачає естетичну, медико-біологічну та технологічну оцінку, в межах яких виокремлено 12 критеріїв для визна- 
чення потенціалу даних об'єктів як заповідних або рекреаційних.

Отже, питання функції парку є ключовим у визначенні підходів та методів дослідження його середовища. Окрім того, функціональне призначення парку нерозривно пов'язане 3 композиційною структурою міста, а їх невідповідність призводить до погіршення стану паркового середовища, що негативно впливає як на екологію, так і естетику урбосередовища загалом. Такі обставини зумовлюють доцільність формування програми дослідження паркового ландшафту, насамперед його естетичних якостей, базуючись на функціях об'єкта (рис. 2).

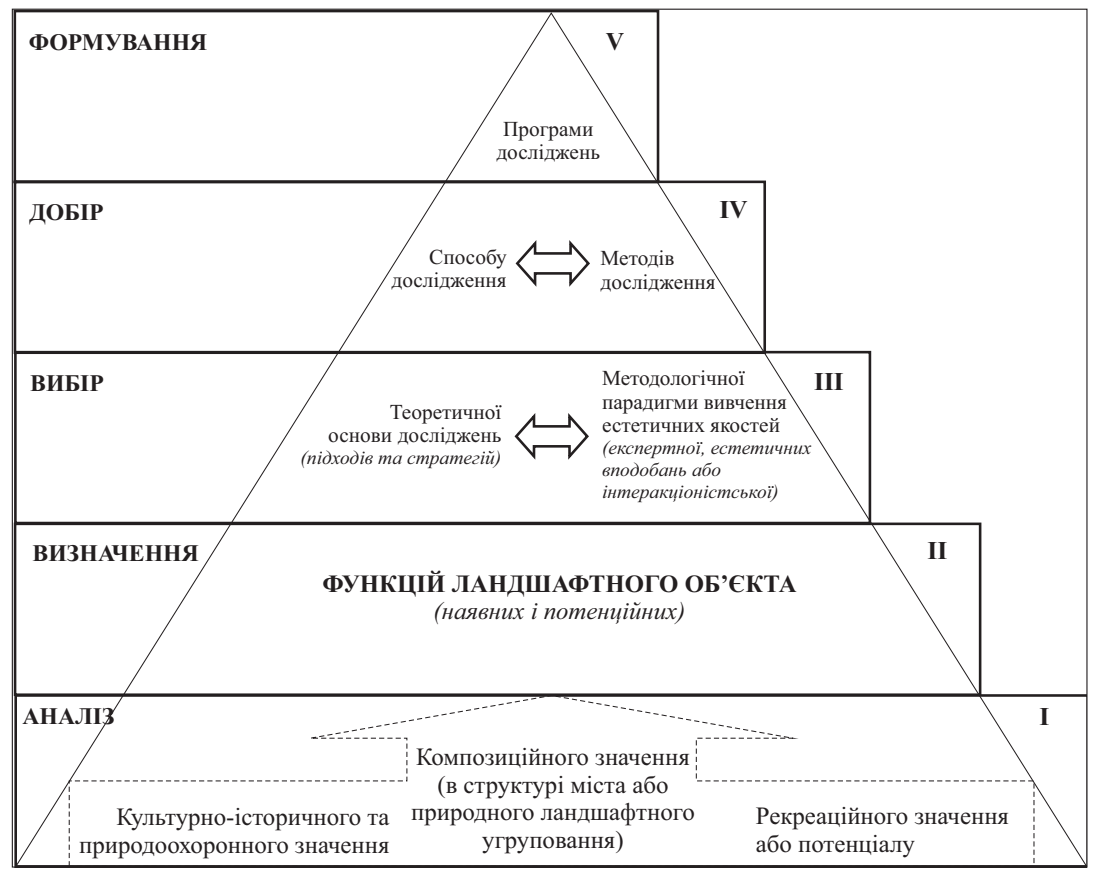

Рис. 2. Концептуальна схема етапів формування програми дослідження естетики паркового середовища та їх взаємозв’язок

Висновки. Вивчення естетики ландшафту як наукового напряму, починаючи з середини XX ст., перебуває у постійному розвитку, а коло його застосування розширюється і нині використовується в різних галузях і сферах як наукової, так і господарської діяльності - від картографії до політики регіонального розвитку ландшафтів.

Оцінювання естетичної привабливості природних ландшафтів базується на визначенні потенційних функцій середовища, а саме спрямовано на виявлення найцінніших ландшафтних угруповань для їх збереження та використання результатів такого оцінювання у формуванні перспективних напрямів розвитку регіону, адаптації окремих територій до потреб населення. Дослідження естетичних якостей ландшафту штучно створених парків різного функціонального призначення здійснюють для визначення рівня їх відповідності сучасним потребам людини та функціям, що на них покладені.

Виявлено, що ключовим питанням у формуванні підходів та визначенні методів дослідження паркового середовища $\epsilon$ його функціональне призначення, що нерозривно пов'язано з композиційною структурою міста, а їх невідповідність призводить до погіршення стану паркового середовища, що негативно впливає як на екологію, так і на естетику урбосередовища загалом.

Запропоновано концептуальну схему формування програми дослідження естетичних якостей парко- вого ландшафту, яка базується на функціональному призначенні (сучасному або потенційному) дослідних об'єктів та передбачає п'ять взаємопов'язаних етапів.

\section{Бібліографічні посилання}

Darabi, H., Razavi, S. S., \& Vaeziheir, A. (2017). Ecological Landscape Planning Considering Landscape Aesthetics (Case Study: Part of Tehran-Qom Freeway) Open Journal of Ecology, 7, 503-507. https// doi.org/10.4236/oje.2017.79034

Dramstad, W.E., Tveit, M.S., Fjellstad, W. J., \& Fry, G.L. A. (2006). Relationships between visual landscape preferences and map-based indicators of landscape structure. Landscape and Urban Planning, 78 (4), 465-474. https//doi.org/10.1016/j.landurbplan.2005.12.006.

Dudyn, R. (2009). The phytocenotic structure of ancient parks and ways of its regulation (on the example of the parks of the West of Ukraine). (candidate of agricultural sciences), The National Forestry and Wood-Technology University of Ukraine, Lviv (in Ukrainian).

Eringis, K., \& Budryunas, A.-R. (1975). The basics and method of the detailed ecological and aesthetical studies of landscapes. Ecology and aesthetics of the landscape, 10-159 (in Russian). 
Filova, L., Vojar, J., Svobodova, K., \& Sklenicka, P. (2015). The effect of landscape type and landscape elements on public visual preferences: ways to use knowledge in the context of landscape planning Journal of Environmental Planning and Management, 58 (11), 2037-2055. https//doi.org/10.1080/ 09640568.2014.973481

Forster, P. M. (2010). A brief introduction to environmental psychology. Charles Darwin University. Date of access: 22/01/2012, Available from: https:// ru.scribd.com/doc/45853873/Introduction-to-Environmental-Psychology

Galushko, R. (1999). Biomorphological signs for ecological and aesthetic assessment of park communities. Bulletin of the state Nikita Botanical Garden, 81, 23-27 (in Russian)

Gatalska, N., \& Lazarenko, Y. (2012). Comprehensive assessment of the decorativeness and state of the plantings of the park in Makarov village, Kyiv region. Scientific Herald of NULES of Ukraine. Series: Forestry and decorative gardening, 2 (171), 229-234 (in Ukrainian)

Hettner A. (1927) Die Geographie. Ihre Geschichte, ihr Wesen und ihre Methoden. Breslau: Ferdinand Hirt Verlag.

Hrozdynskyi, M., \& Savytska, O. (2005). Aesthetics to the landscape. Kyiv: Polihraftsentr 'Kyivskyi universytet' (in Ukrainian).

Hrynasiuk, A. (2014). Methodical bases for assessing of the attractiveness of landscapes. Nature of Western Polissya and surrounding areas, 11, 132-135 (in Ukrainian).

Kane, P. S. (1981). Assessing Landscape Attractiveness: A Comparative Test of Two New Methods. Applied Geography, 1, 77-96. https://doi.org/10.1016/01436228(81)90027-8

Kaymaz I. C. (2012). Landscape Perception. Landscape Planning. [edited by Murat Özyavuz] Rijeka: InTech.

Khoroshikh, O., \& Khoroshikh, O. (1999). Scale of integrated evaluation of decorative features of woody species. Scientific Bulletin: Research, protection and save of biodiversity, 9.9, 167-170 (in Ukrainian).

Klymenko, Y. (2010). Terrain, landscapes and plantations of forest plot «Golendernya» in The State Dendrological Park «Olexandria» of Ukrainian National Academy of Sciences (Bila Tserkva). Scientific reports of NULES of Ukraine, 2 (18), 1-17 (in Ukrainian).

Klymenko, Y. (2011). Assessment of the condition of park plantings and the development of the ways of its optimization (on the example of Holosiivskyi park named after M.T. Rylsky in Kyiv. Bulletin of Poltava State Agrarian Academy, 2 (61), 39-44 (in Ukrainian).

Kucheryavyiy, V. (1999). Urbo-ecological bases of fitomelioration (Vol. 1). Moscow: NPO 'Inform' (in Russian)

Kurbatov, Y. (1988). Architectural forms and natural landscape: compositional connections. Leningrad:
Publishing house of the Leningrad University (in Ukrainian).

Kurdiuk, M. (1982). To the question of estimation of decorativeness of park plantings. In Preservation and restoration of ancient parks (pp. 65-68). Kyiv: Naukova dumka (in Russian).

Margailik, G., \& Kirilchik, L. (1979). To the method of estimating the decorative nature of tree plantations. Bulletin of the Main Botanical Garden, 114, 58-60 (in Russian).

Parkhisenko, L., \& Sesin, V. (2003). Methodical recommendations for conducting aesthetic valuation of the terrain for the purpose of reservation for employees of the network of institutions of the Ministry of Ecology and Natural Resources of Ukraine, scientists, nature guardians. Kyiv: State Service for Reserves of the Ministry of Ecology and Natural Resources of Ukraine, Kyiv Ecological and Cultural Center (in Ukrainian).

Motoshyna, A., \& Vdoviuk, L. (2012). Estimation of aesthetic properties of landscapes of Tobolsk district of Tyumen region for the recreational purposes. «Geographic bulletin » of Perm State University, 4 (23), 10-20 (in Russian).

Nikolaev, V. (2005). Landscape science: aesthetics and design: tutorial. Moscow: Aspekt Press (in Russian).

Oleksiichenko, N. \& Gatalska, N. (2012). Memorial parks of the garden art of the Central highland area of Dnipro river. Kyiv: TsP «KOMPRYNT» (in Ukrainian).

Oleksiichenko, N., Gatalska, N., Podolkhova, M., \& Mavko, M. (2017). Memorial Parks of Kyiv. Bila Tserkva: Oleksandr Pshonkivskyi. (in Ukrainian).

Osychenko, G. (2012). Landscape approach to the analysis of aesthetic qualities of city-planning objects. Problems of theory and history of architecture in Ukraine: collection of scientific papers, 12, 122126 (in Ukrainian).

Osychenko, G. (2015). Methodological basis for the formation of the urban environment aesthetics. (doctor in architecture). Kyiv: National University of Construction and Architecture (in Ukrainian).

Tsaryk, L., \& Cherniuk., H. (2001). Natural recreational resources: methods of evaluation and analysis. Ternopil: Pidruchnyky i posibnyky (in Ukrainian).

Ungar, S. (1999). Environmental perception, cognition and appraisal. Environmental Psychology 4 Lecture Notes, Glasgow Caledonian University, Scotland.

van Etteger, R., Thompson, I.H., \& Vicenzotti V. (2016). Aestheticcreation theory and landscape architecture. Journal of Landscape Architecture, 11 (1), 80-91. doi:10.1080/18626033.2016.1144688.

Zube, E.H., Sell, J.L., \& Taylor, J. G. (1982). Landscape perception - research, application and theory. Landscape Planning, 9 (1), 1-33. https://doi. org/10.1016/0304-3924(82)90009-0. 


\section{Теоретические аспекты функционального назначения парков как основа при формировании подходов к оцениванию эстетических качеств парковой середы}

\section{Н. А. Олексейченко ${ }^{1}$, Н.В. Гатальская²}

По результатам обобщения теоретических и практических научных работ обнаружена принципиальная разница в подходах, научных стратегиях и методах, применяемых в исследованиях эстетики природных и искусственно созданных ландшафтов.

Оценивание эстетической привлекательности природных ландшафтов базируется на определении потенциальных функций среды, а именно направлено на выявление ценных ландшафтных сообществ с целью их сохранения и использования результатов такой оценки при формировании перспективных направлений развития региона, адаптации отдельных территорий в соответствии с потребностями населения. Исследование эстетических качеств ландшафта искусственно созданных парков различного функционального значения проводится с целью определения уровня их соответствия существующим функциям, которые на них возложены.

Выявлено фокусирование внимания ученых на двух аспектах - определение наиболее привлекательных для человеческого восприятия ландшафтов и исследование объективных причин разницы такого восприятия. Сосредоточение внимания ученых на объективных факторах, влияющих на эстетическую привлекательность ландшафтов, способствовало развитию подходов и методов исследования материальных форм ландшафта. В то же время центральное место в исследованиях других ученых занимал человек, как субъект восприятия и оценки эстетики ландшафта.

Выяснено, что ключевым вопросом при формировании подходов и определении методов исследования парковой среды является его функциональное значение, которое неразрывно связано с композиционной структурой города, а их несоответствие приводит к ухудшению состояния парковой среды, что негативно влияет как на экологическую обстановку, так и на эстетику урбосреды в целом.

Обосновано пейзажно-композиционный подход оценки эстетических качеств ландшафтов, объединяющий исследования композиционной структуры

\footnotetext{
Олексейченко Надежда Александровна - действительный член Лесной академии наук Украины, доктор сельскохозяйственных наук, профессор кафедры ландшафтной архитектуры и садовопаркового строительства. Национальный университет биоресурсов и природопользования Украины, ул. генерала Родимцева, 19, г. Киев, 03041, Украина. Тел.: 044-227-82-96, +38-098-33022-78. E-mail: nadiaolex@ukr.net

Гатальская Надежда Викторовна - кандидат сельскохозяйственных наук, доцент кафедры ландшафтной архитектуры и садово-паркового строительства. Национальный университет биоресурсов и природопользования Украины, ул. генерала Родимцева, 19, г. Киев, 03041, Украина. Тел.: 044-227-82-96, +38067-728-69-20. E-mail: gatalska@ukr.net
}

(или отдельных ее составляющих) объекта в сочетании с анализом определенных пейзажей - пейзажных картин и панорам. Предметом пейзажнокомпозиционного подхода является композиционная согласованность компонентов ландшафта в целом и отдельных пейзажей в частности. К методам, которые применяются в пределах пейзажнокомпозиционного подхода, относятся графоаналитический и композиционный анализ, фотофиксация, описание, экспертная оценка. Степень эстетической привлекательности может быть определена как на основе суммарного количества баллов по указанным критериям, так и в соответствии с характеристиками, предоставленными экспертами в описательной форме.

Предложена концептуальная схема формирования программы исследования эстетических качеств паркового ландшафта, основанная на функциональном значении (современном или потенциальном) исследуемых объектов и предусматривает ряд взаимосвязанных этапов. Первым этапом является анализ культурно-исторического, природоохранного и композиционного значения, а также рекреационного потенциала исследуемого объекта с целью определения его современных и потенциальных функций (второй этап). После определения основных второстепенных функций паркового объекта предусмотрено проведение работ, направленных на определение теоретической основы исследований (подходов и стратегий) и методологической парадигмы изучения эстетических качеств (третий этап). На основе парадигмы изучения эстетических качеств предложено произвести отбор методов и способов исследования, которые формируют программу исследований.

Ключевые слова: функции парка, пейзажнокомпозиционный подход, эстетика ландшафта, методология эстетики

\section{The oretical aspects of the functional purpose of parks as the basis for the formation of approaches for aesthetical qualities assessment of park environment}

\author{
N. Oleksiichenko', N. Gatalska²
}

As the result of the theoretical and practical scientific researches generalization the principal difference

\footnotetext{
Nadiia Oleksiichenko - actual member of the Ukrainian Academy of Forest Sciences, Doctor of Agricultural Sciences, Professor of the Department of Landscape Architecture and Park-Gardening Construction of National University of Life and Environmental Sciences of Ukraine, Kyiv, 03041, Ukraine. Tel .:044-227-82-96, +38-098-330-22-78. E-mail: nadiaolex@ukr.net

Nadiia Gatalska - Ph.D. in Agricultural Sciences, Associate Professor of the Department of Landscape Architecture and Park-Gardening Construction of National University of Life and Environmental Sciences of Ukraine, Kyiv, 03041, Ukraine. Tel .:044-227-82-96, +38-067-728-69-20. E-mail: gatalska@ukr.net
} 
in approaches, scientifical strategies and methods used in the study of natural and anthropogenic landscapes aesthetics was found.

The estimation of aesthetical appeal of natural landscapes is based on definition of potential functions of environment, namely, it is aimed at identifying valuable landscape communities with the aim of their preserving and using the results of such an assessment when forming perspective directions of the region's development, adapting individual territories in accordance with the needs of the population. The study of the aesthetic qualities of the landscape of created parks of various functional significance is conducted for the purpose of determining the level of their compliance with the existing functions that are assigned to them.

It was identified the focus of scientists' attention on two aspects - the determination of the most attractive landscapes for human perception and the study of objective reasons for the difference in such perception. Focusing of scientists' attention on objective factors that influence the aesthetic appeal of the landscapes promoted the development of approaches and methods for studying the material forms of the landscape. At the same time, the central place in the researches of other scientists was taken by man, as subject of perception and estimation of the aesthetics of the landscape.

It was found out that the key issue in the approaches formation and the research methods definition for the park environment is its functional significance, which is inextricably linked with the composition structure of the city, and their inconsistency leads to the deterioration in condition of the park environment, which in turn negatively affects both the ecological situation and the aesthetics of the urban environment in general.

The landscape and compositional approach in the aesthetic qualities of the landscapes assessment, com- bining researches of the composition structure (or its individual components) of the object in combination with the analysis of certain landscapes - landscape views and panoramas - is grounded. The subject of the landscape and compositional approach is the compositional conformity of the landscape components in general and certain landscapes in particular. The methods used in the range of the landscape and compositional approach include graphic-analytical and compositional analysis, photo fixation, description, scientific assessment. The level of the aesthetical appeal can be determined both on the basis of the sum of points on the specified criteria, and in accordance with the characteristics provided by experts in a description form. The conceptual scheme of the formation of research program for the of aesthetic qualities of the park landscape is proposed. It's based on the functional significance (current or potential) of the objects under the research and provides a number of interrelated stages. The first stage is the analysis of cultural and historical, environment-oriented and compositional significance, as well as the recreational potential of the object under the research for the purpose of determination its current and potential functions (the second stage). After determining the main secondary functions of the park object, it is envisaged to carry out works aimed at determining the theoretical basis of research (approaches and strategies) and the methodological paradigm for studying aesthetic qualities (the third stage). On the basis of the paradigm of the study of aesthetic qualities, it is suggested to select methods and ways of research, which in turn form the research program.

Key words: park functions, landscape and compositional approach, aesthetic of landscape, methodology of aesthetics 